\title{
Re-selection of College English Teaching Contents under Economic Integration
}

\author{
Liu Lei ${ }^{1, a}$ \\ ${ }^{1}$ Department of English,Tianhe College Of Guangdong Polytechnic Normal \\ UniversityGuangzhou, Guangdong,China, 510000 \\ azhiren007@163.com
}

Keywords: colleges, English teaching, teaching content, economic integration

\begin{abstract}
With intensive development of regional economic integration and China's growing enthusiasm taking part in the international affairs, English has never served so much connecting China with the world, putting forward higher requirement on the country's college English teaching. Aimed at the problems exited in China's college English teaching such as a higher proportion of Western culture, fuzzy goal planning and coarse contents of Chinese culture etc, this paper suggests the re-selection strategies of China's college English teaching contents under the background of economic integration. The suggestions, including making Chinese culture curriculum independent, enriching its proportion and emphasizing more on cross-culture communication, would help to solve the problem of Chinese cultural aphasia in China's college English teaching, improving the teaching mode.
\end{abstract}

\section{Introduction}

With the main trend of economic globalization and the rapidly development of foreign economy and trade in various countries since the reform and opening, English has become the universal language of the world, an important tool for countries engaging in the international competition and cultural communication and the indispensable ability for individuals meeting the social development and taking part in international communication.

Shouldering the load of imparting knowledge and cultivating people, colleges and universities should pay attention to students' English comprehensive abilities especially writing and speaking with the wild spread application of English to ensure their effective oral and writing expressions during the working process and social interaction.

Content selection of college English teaching is now facing new challenges from social development and international communication providing talents adapted to the society and market with enhanced self-learning abilities and improved comprehensive cultural accomplishments.

\section{Problems in the content selection of China's college English teaching}

English, now a language that must command, floods the daily life and occupies an important position in working and studying. English learning and teaching is the point of all levels of education where college English teaching being the center mainly cultivating high qualified talents for the community. Improved students' quality can better serve the society [1].

Having obtained certain achievements, problems, however, still exit in present China's college English teaching [2]. To further solve these questions and to adapt to the demands of development of society and times in improving the teaching quality, this paper tried to give suggestions and opinions on studying deficiencies of China's college English teaching.

Here are the detailed analyses.

A The high proportion of Western culture in China's college English teaching

Foreign textbooks and publications are largely introduced in China's traditional English teaching system, leading to the lack of Chinese culture in English teaching content, which are mostly about 
Western culture and custom. The transfusing of Chinese culture lost its due position in China's college English teaching.

Longfu Xiao and Di Xiao made analyses on the cultural background and contents of the reading materials in two sets of textbooks used in China's college English teaching in their research Status Quo of Chinese Cultural Aphasia in China's College English Teaching [3]. It revealed that the four books of College English-Integrated Course contains 64 reading materials including forty-four (accounting 69\% of the total) concerning British or American cultures with only one (1\% of the total) related with Chinese culture. There are 96 reading materials in the four books of Experiencing English Integrated Coursebook, four (4\%) of them talking about Chinese culture and fifty-one (53\%) are about English-speaking countries.

Details are shown in Fig. 1 and Fig. 2.

Presently either required or selected courses concerning Western cultural backgrounds are easily found in most colleges and universities while courses about Chinese cultures and customs are rare. The weakening of the instructional communication of Chinese culture, one of main reasons of students' Chinese cultural aphasia, is the result of the imperfectness of the college teaching system, the staleness of the teaching ideas and the students' disinterest, undervalue and ignorant to Chinese culture.

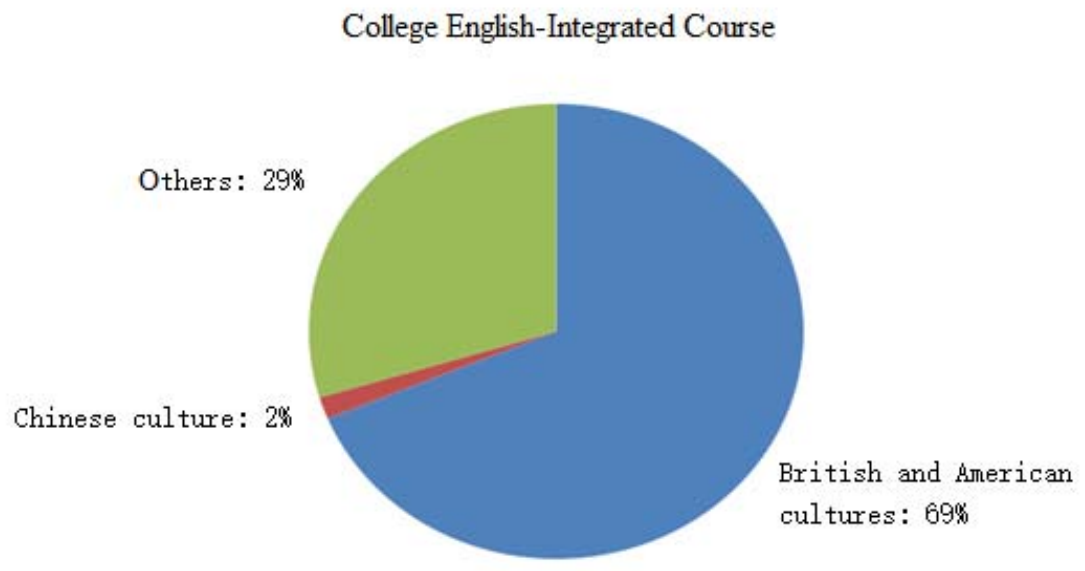

Fig.1 culture teaching contents' proportions in College English-Integrated Course Experiencing English Integrated Coursebook

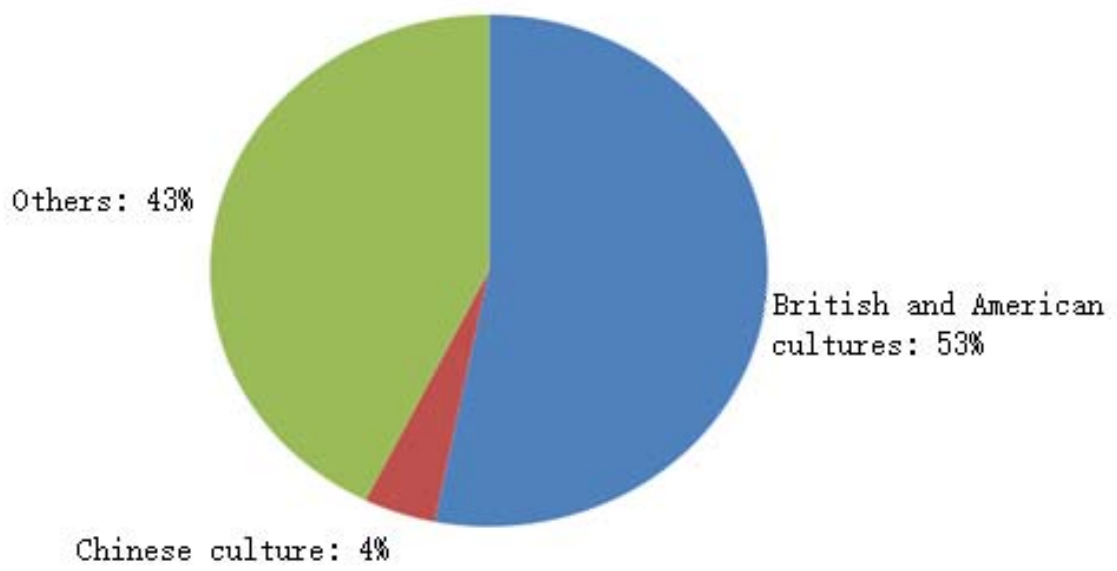

Fig.2 culture teaching contents' proportions in Experiencing English Integrated Coursebook

B Vague goals of Chinese cultural teaching in China's college English teaching

Syllabus or the teaching goals it sets, deciding the textbook compiling, teaching contents, selection of teaching methods and the curriculum deployment, is the baton of a country or a region's teaching. 
According to the Syllabus for English Majors in China, curriculum set for English majors should include three sectors: professional English skills, professional English knowledge and related professional knowledge, generally instructed in English. There are definite requirements that lessons of Chinese culture are indispensable, students are required to "know the traditional Chinese culture, equip with certain artistic accomplishments and well-trained basic skills in Chinese".

The College English Curriculum Requirements asked the culture teaching in China to "improve students' comprehensive culture accomplishments to meet the demands of China's economic development and international communication". The requirements can be divided into three levels according to the different conditions of regional college education and a higher one is that college students should be able to "translate articles reflecting China's conditions or introducing Chinese culture".

Requirements from the above two English teaching syllabuses showed that the government, while set the targets of college English teaching, failed to make further descriptions on practical implement measures. Therefore, universities and colleges, understanding the syllabuses in different perspectives, set their own curriculums according to their actual teaching environments and conditions.

The too wild set syllabuses provide no specialized directions and thus leading to colleges' ignorant to the realization of Chinese culture teaching targets.

C Rough teaching contents of Chinese culture in China's college English teaching

The author made random testing for some English major teachers and students in two colleges in Liaoning, discussing the teaching proportion of Chinese culture in the college English teaching.

Most teachers $(87 \%)$ and students $(83.7 \%)$ interviewed agreed that there are little teaching contents in textbooks used now, and a majority of them (87.5\% teachers and $83.7 \%$ students) agreed that teachers rarely supply additional knowledge of Chinese culture in classes. As for the reading materials on Chinese culture, most of them $(93.8 \%, 83.8 \%)$ believed that it is not easy finding English materials of college level.

All these revealed that students interviewed had little opportunities obtaining knowledge and English expressions of Chinese culture. Details are shown in Fig.3.

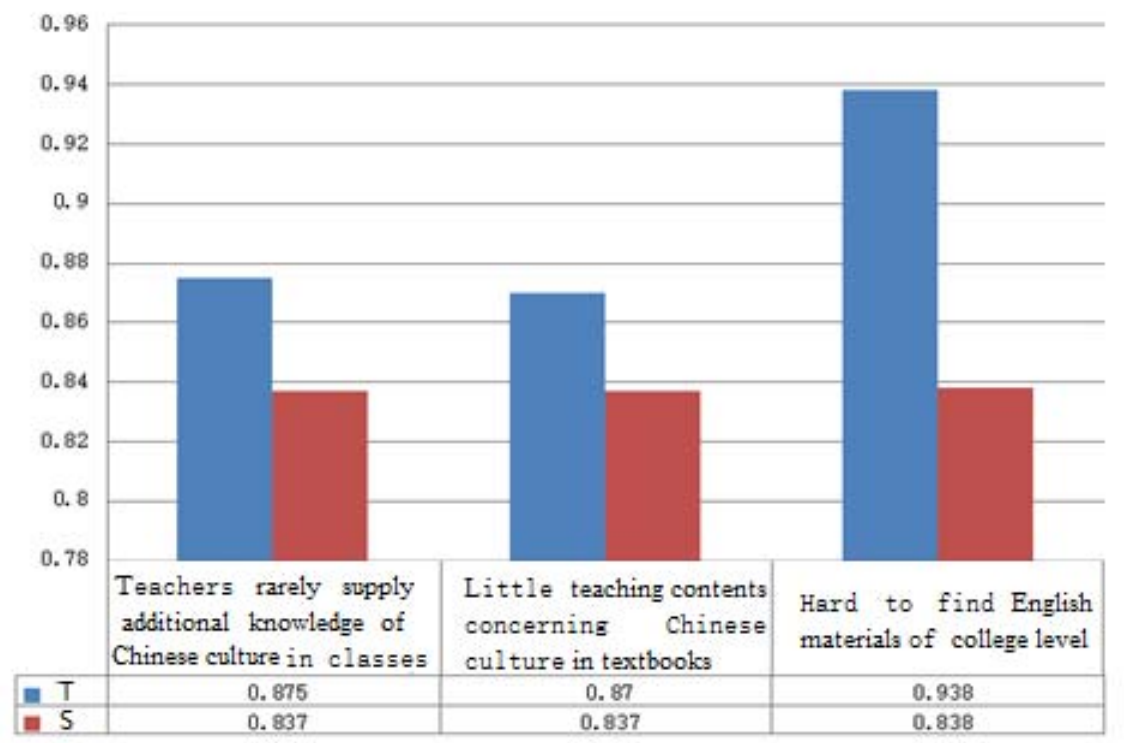

Fig. 3 survey of Chinese culture contents in English teaching

What can be seen from the above survey is that most colleges fail to follow the requirements set by the syllabus of college English teaching to develop courses for Chinese culture which can rarely find in English textbooks.

Isolated with Chinese culture and customs in class, it is now common that college students with little related extra-curriculum reading materials cannot express them in good English. 


\section{Re-selection of college English teaching contents under economic integration}

How to solve the Chinese cultural aphasia? How to improve students' abilities to communicate Chinese culture with good English? How to get the two-way transmission of culture? There are all challenges puzzling the education circle.

Contain Chinese culture in college English teaching is an important way solving Chinese cultural aphasia, but how to?

There are three ways: setting an independent Chinese cultural curriculum in English teaching, enriching the teaching contents of Chinese culture and improving students' abilities of crosscultural communication skills.

A An independent Chinese cultural curriculum in English teaching

Firstly, correspondent courses should be set according to the syllabus of college English teaching and the school's actual condition, added step by step in learning Western culture. The mode of gradually infiltrating was applied to combine Chinese cultural teaching with the core curriculum of college English teaching. Independent Chinese cultural courses can then be set with students' acceptance in required or selective courses.

Teachers should stimulate students' interest in Chinese culture breaking the stiff textbooks and selecting abundant extra curriculum cultural materials along with project research. Chinese cultural aphasia can then be avoided better combing Chinese culture with English.

B Enriched Chinese culture content in English teaching

In China, professional cultural studying scholars are almost the only group specialized in Chinese culture, college English teachers, whose proficiency in foreign cultures form a contrast with their knowing in their own one. It is impossible to impart Chinese culture to their students without abundant knowledge.

All countries are carrying out national cultural protection at present, China, famous for its 5000 years history and culture, is of no exception. Being the backbone elements of imparting knowledge and cultivating people, college English teachers should improve their understanding in Chinese culture to encourage the students knowing more about this nation.

Adding the contents of Chinese culture into college English teaching, an inexorable trend in China's college education, is the deepening of language teaching rather than the shifting of the teaching point.

Combining foreign teaching ideas with Chinese culture, college English teachers should blend the cultural elements into every link of English teaching with constant renewed teaching contents and methods, thus gradually solve the Chinese cultural aphasia Infiltration of Chinese culture content in College English teaching, transfer is not the College English teaching focus, deepening but in language teaching, but also the inevitable trend of the development of China's College English teaching.fundamentally. English as a bridge of international communication can achieve when students can introduce Chinese culture in good English.

C Improved cross-cultural communication skills teaching

In cross-cultural communication which cultivates the communicative competence in cultural and knowledge identification of students, needs their introducing Chinese culture and express themselves in English, which can be enhanced by converting learned knowledge into their own unique spiritual values.

Teachers of college English cross-cultural teaching should impart knowledge to students, the host of class, and lead them to autonomous learning and be responsible for textbook compiling and teaching modes selecting. Students, with the guidance of their teachers, have their own understandings on Chinese culture. They would experience different meaning constructions with different mental feelings and value orientation in tasting and comprehending the language and culture.

Limited class is not enough learning Chinese culture, extra curriculum reading materials are indispensable for either teachers or students. What the difference between cross-cultural English teaching and the traditional one line teaching is that the former asks for the bilingual intersecting. 
The really important thing is that students know how to express Chinese culture with English. The intersection of Chinese and foreign cultures would definitely improve the comprehensive and integration abilities students, who can then accept different cultural information with their own keen insight. Their improved accomplishments prepare adaptability and essential foreshadowing for their

\section{Conclusion}

With investigation, this paper made bit by bit analyses on the influential elements causing Chinese cultural aphasia from the teachers' layer, textbooks' layer and the absented Chinese cultural layer, defining the reselection direction of college English teaching contents.

Emphasizing on the phenomenon of Chinese cultural aphasia in college English teaching, this paper made demands on teachers of improving themselves and being specialized in Chinese culture. Guidance and inspiration to students according to the targets set by the syllabus of college English teaching are essential making students comprehend Western and Chinese cultures at the same time to popularize our own culture. Only with this can English fully play the role of communicating.

\section{References}

[1] Standards for Foreign Language Learning. Preparing for the 21 Century.http:

//Spunish.about.com/gi/dynamic/offsite.htm?site=http://www.actfl.orh/.2009

[2] Holec,Henri. Foreword. Learner and Teacher Autonomy: Concepts, Realities, and Responses . 2008

[3] David Moguel. Teaching About Language, History and Culture through Music. Multilingual Educator. 2008

[4] Nick C.Ellis. Emergentism, Connectionism and Language Learning[J]. Language Learning . 2008 (4) 